\title{
Detection of Salmonella typhimurium ATCC 14028 in supplement health product liquid preparation using Real-Time PCR (qPCR)
}

\author{
ALFI SOPHIAN ${ }^{1, \vartheta}$, RATNA PURWANINGSIH ${ }^{1}$, BERTHA LOLO LUKITA ${ }^{2}$, ENI CAHYA NINGSIH ${ }^{2}$ \\ ${ }^{1}$ Laboratorium of National Agency of Drug and Food Control in Gorontalo. Jl. Tengah Toto Selatan, Bone Bolango 96123, Gorontalo, Indonesia \\ Tel./fax.: +62-435-22052, `email: alfi.sophian@pom.go.id \\ ${ }^{2}$ Management of Centre of National Quality Control Development of Drug and Food. Jl. Percetakan Negara No. 23, Jakarta Pusat 10560, Jakarta, \\ Indonesia
}

Manuscript received: 6 April 2020. Revision accepted: 7 July 2020.

\begin{abstract}
Sophian A, Purwaningsih R, Lukita BL, Ningsih EC. 2020. Detection of Salmonella typhimurium ATCC 14028 in supplement health product liquid preparation using Real-Time PCR (qPCR). Biofarmasi J Nat Prod Biochem 18: 65-69. Detection of Salmonella typhimurium ATCC 14028 using Real-Time PCR (qPCR) on health supplement products was carried out in the microbiology and molecular biology testing laboratory of the Food and Drug Supervisory Office in Gorontalo. The purpose of this study was to provide an alternative testing method reference in the testing of liquid supplement health supplement products in the market. The sample consisted of 35 samples of liquid supplement health supplements spike with positive control of Salmonella typhimurium ATCC 14028 phase 2. The method used in the study was qPCR analysis using the SYBR Green method, whereas DNA isolation using the direct PCR method. Data analysis was performed based on 2 main criteria: (i) $\mathrm{Ct}$ (Cycle threshold) analysis, which looks at the value of the sample Ct and compares it with controls, and (ii) analysis of melting temperature (Tm), which is the melting point at the temperature at which melting occurs and comparing the melting point to the positive control. The results showed that Salmonella typhimurium ATCC 14028 was detected in the sample at an average $\mathrm{Ct}$ value of 14.43 and an average Tm value of 86.05 ; for the specificity, LOD and positive control tests were all amplified. For negative controls, $\mathrm{Ct}$ and Tm values were not detected. Based on these data, it can be concluded that real-time PCR (qPCR) can be used to detect Salmonella typhimurium ATCC 14028 in liquid supplement health supplement products.
\end{abstract}

Keywords: Health supplement, phase, qPCR, Salmonella typhimurium, SYBR green

Abbreviations: HEA: Hekton Enteric Agar, LOD: Limit of detection, TSA: Tryptic Soy Agar, TSB: Tryptic Soy Broth, XLD: Xylose Lysine Desoxycholate Agar

\section{INTRODUCTION}

Health supplements are products intended to fulfill nutritional needs, maintain, enhance or improve health functions, have nutritional value or physiological effects, and contain one or more ingredients in the form of vitamins, minerals, amino acids, and other non-plant ingredients which can be combined with plants. Health supplements can be made in the form of tablets, pills, capsules, oral liquids, powders, and granules or gummies. Health supplements must be made by using safe, useful, and quality raw materials by the provisions of the Indonesian Pharmacopoeia, Indonesian Herbal Pharmacopoeia, other countries' pharmacopeia, or recognized scientific references (NADFC 2019). To support the safety of the quality of health supplement products available on the market, it is necessary to have the latest test methods developed according to the advancement of science and technology. One such latest method is molecular analysis to detect pathogenic bacterial contamination in health supplements.

Molecular analysis to identify pathogenic bacteria using real-time PCR has advantages over conventional methods. The average time required if the identification of pathogenic bacteria is made conventionally is about 3-5 days, whereas it only takes 50-52 hours if the PCR method is used as an isolation technique ( 24 hours for enrichment samples, 24 hours for selective enrichment, and 1.5 hours for real-time PCR analysis).

One of the quality check parameters of health supplement products is that they should be free from pathogenic Salmonella bacteria: therefore, the mechanism of Salmonella identification is becoming increasingly necessary. The polymerase chain reaction (PCR) is among the several molecular techniques used in detecting Salmonella most commonly used is the polymerase chain reaction (PCR). Real-time PCR analysis (qPCR) shows high sensitivity and reproducibility in amplifying certain DNA fragments and can measure the presence of Salmonella DNA (Oliveira et al., 2018).

In recent years, several studies on the detection of Salmonella in various samples such as meat and poultry (Catarame et al. 2006); raw pork sausages (Wang et al. 2004); pasteurized milk, ground beef, and sprouts (Mercanoglu et al. 2005); water and milk (Jothikumar et al. 2003); samples of prepared foods, raw meat, and poultry (Cheung et al. 2004); minced beef, fish and raw milk (Perelle et al. 2004); raw and ready-to-eat beef products (Ellingson et al. 2004); and chicken intestines, cloacal 
swabs, chicken carcasses (Eyigor et al. 2003; Eyigor et al. 2002) have been carried out.

According to Brooks et al. (2007), Salmonella can cause enteric fever caused by Salmonella typhi called Typhoid fever, Septicemia, a fever caused by Salmonella choleraesuis, and Gastroenteritis, a digestive tract disease caused by food poisoning that contains Salmonella typhimurium.

NADFC Regulation No. 17 of 2019 concerning Quality Requirements for Health supplements regulates the contamination limits of pathogenic bacteria in health supplements, where herbal-based health supplements may not contain pathogenic bacteria like Salmonella spp. Health supplement quality requirements must be applied before supplements are in circulation during health. Therefore, monitoring the product is very important to ensure that the circulating products are free from pathogenic bacterial contaminants. The quality requirements for health supplements must comply with the Indonesian Pharmacopoeia and Indonesian Herbal Pharmacopoeia provisions. Based on this, the research was conducted to develop alternative methods for detecting Salmonella in liquid supplement health supplement products.

\section{MATERIALS AND METHODS}

\section{Materials}

The sample materials used in this study were liquid health supplements, distilled water, TSB enrichment media, TSA, XLD, and HEA selective media; the PCR kit uses QuantiNova SYBR Green (Qiagen).

\section{Sample setup}

A total of 35 samples of liquid supplement health supplements spike with positive control of Salmonella typhimurium ATCC 14028 phase 2 were used during the present study.

\section{Isolation in selective media}

For isolation, 10 grams sample for solid samples were weighed out while it was pipette out $10 \mathrm{ml}$ for a liquid sample. To this, $90 \mathrm{~mL}$ TSB was added and then incubated at 35-37C for 18-24 hrs. After incubation, one sample was scratched on the HEA and XLD selective media and then incubated at $35-37 \mathrm{C}$ for $18-24 \mathrm{hrs}$. Observations of colonies growing on selective media were recorded at regular intervals.

\section{DNA isolation}

DNA isolation was not carried out because the direct PCR method was used. The results of isolation from selective media were then enriched on the media to be skewed. The enrichment results stabilized in physiological $\mathrm{NaCl}$ and equalized to standard $1 \mathrm{MacFarland}$. The results of this equalization were then used as DNA templates.

\section{qPCR analysis}

Cycling and melt curve analysis was carried out using qPCR (QIAGEN 5 Plex) with the 2-step cycling method:
Denaturation $95^{\circ} \mathrm{C}$ for $45 \mathrm{sec}$ and Annealing/Extention $60^{\circ}$ $\mathrm{C}$ for $45 \mathrm{sec}$. The primer used to detect Salmonella typhimurium using InvA Forward primers (5'-ATC AGT ACC AGT CTT ATC TTG AT-3 '), reverse (5'-TCT GTT TAC CGG GCA TAC CAT-3 ').

\section{Reaction setup}

The total volume of the master mix was $10 \mu \mathrm{L}$ consisting of $5 \mu \mathrm{L}$ Sybr green master mix, $1 \mu \mathrm{L}$ forward primer, $1 \mu \mathrm{L}$ reverse primer, $1 \mu \mathrm{L}$ water-free RNase, and 2 $\mu \mathrm{L}$ DNA template.

\section{Positive control}

The positive control used was Salmonella typhimurium ATCC 14028 phase 2, which was enriched and etched on the media to make it tilt. Salmonella typhimurium ATCC 14028 colony was then dredged in physiological $\mathrm{NaCl}$ and equalized to standard 1 MacFarland.

\section{Negative control}

NTC (No Template Control) was negative control, a master mix combined with primers and free water from nucleic acids. The total negative control volume was $10 \mu \mathrm{L}$ consisting of; master mix Sybr green, $1 \mu \mathrm{L}$ forward primer, $1 \mu \mathrm{L}$ reverse primer, and $3 \mu \mathrm{L}$ RNase free water.

\section{Specificity}

Specificity testing was done by mixing the Salmonella typhimurium ATCC 14028 colony with the colony of Escherichia coli ATCC 25922 and Listeria monocytogenes ATCC 7644 in a ratio of 1: 1: 1 using the reference standard 1 MacFarland.

\section{LOD}

For LOD analysis, it was done by adding a 10: 1 sample DNA template from a positive DNA control template. In the positive control, the DNA template used was $2 \mu \mathrm{L}$, then the DNA template for LOD was $0.2 \mu \mathrm{L}$.

\section{Data analysis}

Data analysis was carried out based on 2 main criteria, which included: (i) $\mathrm{Ct}$ (Cycle threshold) analysis which looked at the value of sample $\mathrm{Ct}$ and compared it with controls. (ii) Analysis of melting temperature (Tm), the melting point at the temperature at which melting occurs, compares the melting point to the positive control.

\section{RESULTS AND DISCUSSION}

\section{Isolation in selective media}

The results of observations on HEA and XLD selective media can be seen in Figure 1. Based on the isolation results on HEA selective media, the colony was grey to black in the middle, while on XLD media, it was translucent to black in the center. 

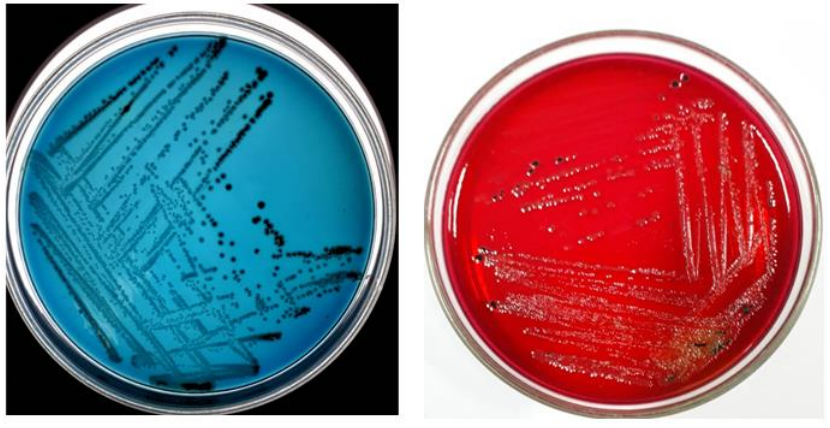

Figure 1. Salmonella profile on selective media HEA (blue) and XLD (red)

The choice of HEA and XLD selective media is because these two selective media are specific media for the isolation of Salmonella pathogenic bacteria. Andrews et al. (2007) explained that the profile of Salmonella on HEA and XLD media has a similar shape, which is the presence of black spots or not in the middle of the colony. A different matter was stated by Murray et al. (1999), which states that the HEA and XLD media are often used together to detect Salmonella because both of these media can also isolate Shigella. Both HEA and XLD have H2S indicators that can detect Salmonella from lactose-positive indicators.

\section{Real-time PCR analysis}

PCR real-time analysis was performed using the qualitative SYBR green method, and the results are presented in Table 1.

Based on the analysis of 35 samples, the obtained results showed that all samples detected were positive for Salmonella typhimurium ATCC 14028, as seen from samples compared with positive controls. The detection limit used was 1:10 from the sample template. This comparison was set because there is no definite standard of LOD in detecting Salmonella typhimurium ATCC 14028. It is determined by itself with a dilution system 10 times smaller than the DNA template. The specificity test was made from 2 groups of gram-negative and gram-positive bacteria to see if there was an influence on the ability of the method to detect specific DNA. The Escherichia coli ATCC 25922 were selected because these bacteria belong to the same gram-negative group as Salmonella

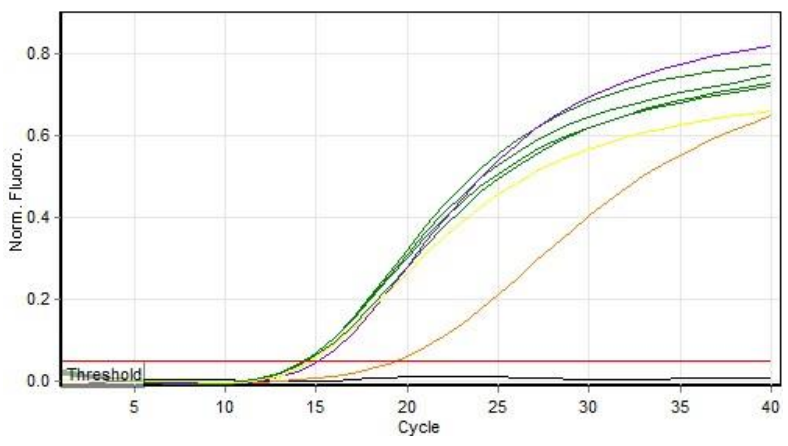

Figure 2. $\mathrm{Ct}$ analysis typhimurium ATCC 14028. Listeria monocytogenes ATCC 7644 represents a group of gram-positive bacteria.

The results of cycling analysis by looking at the $\mathrm{Ct}$ value showed that the qPCR analysis showed Salmonella typhimurium ATCC 14028 in samples detected at Ct 14.43, LOD with a spike of positive control 10 times smaller than the sample turned out to be able to be detected at Ct 14.8, specificity was detected at $\mathrm{Ct} 19.47$ difference. This is quite far from the value of $\mathrm{Ct}$ samples, and LOD against $\mathrm{Ct}$ specificity indicates that the addition of templates from Escherichia coli ATCC 25922 and Listeria monocytogenes ATCC 7644 influence the ability to detect $\mathrm{Ct}$ values. Several factors can also cause positive control at 15.7 different $\mathrm{Ct}$ values. The PCR direct concentration method and DNA template purity were not carried out in the measurement process. The template concentration between the sample and control was not the same. The $\mathrm{Ct}$ values could be different. Negative controls give unamplified results. This gives information that the master mix or in the test process does not occur contamination of the sample and positive control, as shown in Figure 2.

The results of the melt curve analysis by looking at the Tm value showed that the qPCR analysis showed Salmonella typhimurium in samples detected at Tm 86.05, LOD at $\operatorname{Tm} 86.0$, specificity at $\operatorname{Tm} 83.8$, and positive control at $\mathrm{Tm}$ 85.2. While the negative control did not show any Tm value due to not being amputated in the qPCR amplification process, as shown in (Figure 3). As with the $\mathrm{Ct}$ analysis, the difference in the value of $\mathrm{Tm}$ was also directly proportional to the difference in the value of Ct. This was because the DNA template used was not analyzed for its purity and concentration. DNA isolation PCR direct technique was used, and the concentration of samples, positive control, LOD, and sensitivity are unknown.

Table 1. qPCR data analysis

\begin{tabular}{lccccc}
\hline \multirow{2}{*}{$\begin{array}{c}\text { qPCR } \\
\text { analysis }\end{array}$} & Sample $\begin{array}{c}\text { Negative } \\
\text { control } \\
\text { (NTC) }\end{array}$ & LOD & Specificity & $\begin{array}{c}\text { Positive } \\
\text { control }\end{array}$ \\
\hline Ct values & 14.43 & - & 14.8 & 19.47 & 15.7 \\
Tm values & 86.05 & - & 86.0 & 83.8 & 85.2 \\
\hline
\end{tabular}

Note: $\mathrm{Ct}$ and $\mathrm{Tm}$ values are the average value of 35 data replications

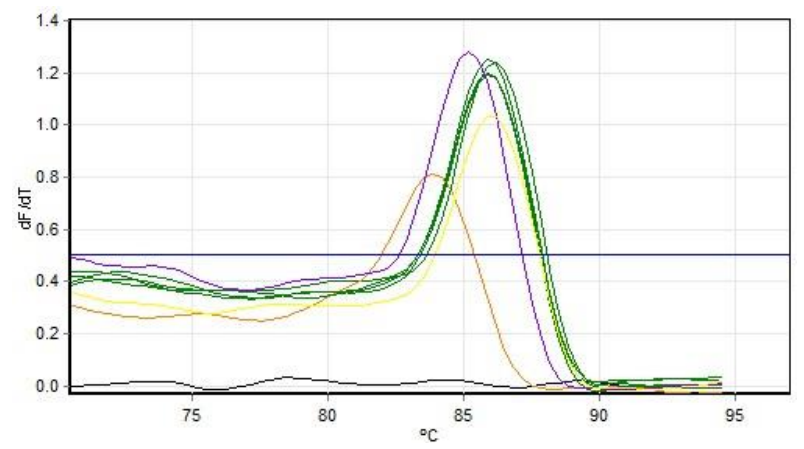

Figure 3. Melt curve analysis (Tm) 


\section{Discussion}

Detection of Salmonella in liquid supplement health supplement products using real-time PCR was carried out by a qualitative method using the Quantinova SYBR Green (Qiagen) kit. This study was conducted using a sample of 35 liquid supplement packs on the spike with Salmonella typhimurium ATCC 14028, while for specificity used, Escherichia coli ATCC 25922 and Listeria monocytogenes ATCC 7644.

XLD media gave positive results of Salmonella by positive control, namely translucent spherical colonies with black spots in the middle. These results align with research conducted by Maddocks et al. (2002) and Nye (2002). According to Braid et al. (1995), the color change is based on observations of the HEA selective media (Figure 1) shows that on selective media, the colonies are greenishblue with or without black at the center of the colony. Many colonies can be glossy black or appear to be almost entirely black in large concentrations or cultures (BAM 2007). HEA is a selective media that does not have the ability to selectivity like XLD. Gaillot et al. (1999) tested 508 Salmonella samples using HEA, with 16 results being detected as false positive; in other words, $96 \%$ showed positive results, and $4 \%$ showed false-positive results.

According to Oliveira et al. (2018), molecular analysis for the detection of Salmonella using real-time PCR showed considerable sensitivity and reproducibility in the amplification of certain fragments. It could measure the presence of Salmonella DNA. Molecular research in species detection has been developed in various forms of modification. A study of the identification of Salmonella using real-time PCR, conducted by Piknova et al. (2002) on 75 types of Salmonella strains using the SYBR green method, gave $100 \%$ detectable results. The real-time PCR analysis was performed using the 2 -step cycling method: Denaturation $95^{\circ} \mathrm{C}$ for $45 \mathrm{sec}$ and annealing/extension $60^{\circ}$ C for $45 \mathrm{sec}$.

The genes used in this study were invA genes with primary sequences forward (5'-ATC AGT ACC AGT CTT ATC TTG AT-3'), reverse (5'-TCT GTT TAC CGG GCA TAC CAT-3'). The invA gene as the primer was selected because the invA gene is a specific gene to identify Salmonella typhimurium ATCC 14028. The use of invA genes for Salmonella detection using real-time PCR has been developed and validated by Malorny et al. (2003). According to Patel et al. (2006), validation is very important in making standard methods to provide accurate results.

The Tm value in the qPCR analysis is influenced by the composition and size of the nucleotides. Fluorescent signals give information when DNA bands begin to separate after the annealing process. The melt curve produces a specific single peak of each band detected. However, in each melt curve analysis, the presence of double peaks can sometimes also occur, but even so, the double peaks that occur do not say that this method is not specific (Dwight 2011).

To evaluate real-time PCR tests to detect pathogens in various matrices, both the sensitivity and specificity of the test need to be determined. The analytical sensitivity of a test has been defined as the smallest amount detected from the analyte in question. In contrast, analytical specificity is the extent to which the test does not cross-react with other analytes (Bohaychuk et al., 2006).

Health Supplements are products intended to supplement nutrition. The conclusion that can be drawn from this study is the use of real-time PCR with the SYBR Green method to identify Salmonella typhimurium ATCC 14028 in 35 samples giving $100 \%$ detected results.

\section{ACKNOWLEDGEMENTS}

The authors would like to thank the Head of the National Agency of Drug and Food Control (NADFC) in Gorontalo, Indonesia, for laboratory support.

\section{REFERENCES}

Andrews WH, Wang H, Jacobson A, Hammack T. 2007. Bacteriological Analytical Manual. Chapter 5. Salmonella. BAM. https://www.fda.gov/food/laboratory-methods-food/bam-chapter-5Salmonella

Baird R, Curtis G, Corry J. 1995. Culture Media for Food Microbiology, Vol. 34. Elsevier Science, Amsterdam.

Bohaychuck VM, Gensler GE, McFall ME, King RK, Renter DG. 2006. A Real-Time PCR assay for the detection of Salmonella in a wide variety of food and food-animal matrices. J Food Prot 70 (5): 10801087

BPOM. 2019. Regulation of the Food and Drug Supervisory Agency Number 16 of 2019. Concerning Supervision of Health Supplement. Republic of Indonesia Food and Drug Supervisory Agency. [Indonesian].

Brooks GF, Carroll KC, Butel JS, Morse SA. 2007. Medical Microbiology (Jawetz, Melnick \& Adelberg's Medical Microbiology). 24th ed. McGraw Hill Professional, New York.

Catarame, T. M. G. 2006. Comparison of a real-time polymerase chain reaction assay with a culture method for the detection of Salmonella in retail meat samples. J Food Saf 26: 1-15.

Cheung, PY, Chan CW, Wong W, Cheung TL, Kam KM. 2004. Evaluation of two real-time polymerase chain reaction pathogen detection kits for Salmonella spp. in food. Lett. Appl Microbiol 39: 509-515.

Ellingson JL, Anderson JL, Carlson SA, Sharma VK. 2004. Twelve-hour real-time PCR technique for the sensitive and specific detection of Salmonella in raw and ready-to-eat meat products. Mol Cell Probes 18: 51-57.

Eyigor A, Carli KT, Unal CB. 2002. Implementation of real-time PCR to tetrathionate broth enrichment step of Salmonella detection in poultry. Lett Appl Microbiol 34:37-41.

Eyigor A, Carli KT. 2003. Rapid detection of Salmonella from poultry by real-time polymerase chain reaction with fluorescent hybridization probes. Avian Dis 47: 380-386.

Jothikumar N, Wang X, Griffiths M W. 2003. Real-time multiplex SYBR green I-based PCR assay for simultaneous detection of Salmonella serovars and Listeria monocytogenes. J Food Prot 66: 2141-2145.

Maddocks S, Olma T, Chen S. 2002. Comparison of CHROM agar Salmonella Medium and Xylose-Lysine-Desoxycholate and Salmonella-shigella agars for isolation of Salmonella Strains from stool samples. J Clin Microbiol 40 (8): 2999-3003.

Malorny B, Hoorfar J, Bunge C, Helmuth R. 2003. Multicenter Validation of the Analytical Accuracy of Salmonella PCR: towards an International Standard. Appl Environ Microbiol 69: 290-296.

Mercanoglu B, Griffiths MW. 2005. Combination of immunomagnetic separation with real-time PCR for rapid detection of Salmonella in milk, ground beef, and alfalfa sprouts. J Food Prot 68: 557-561.

Murray PR, Baron EJ, Pfaller MA, TenoverFC, Yolken RH. 1999. Manual of Clinical Microbiology, ASM Press, Washington D.C. USA. 
Nye KJ, Fallon D, Frodsham D, Geel B, Howel S, Messer S, Turner T, Warren RE. 2002. An evaluation of the performance of XLD, DCA, $\mathrm{MLCB}$, and $\mathrm{ABC}$ agars as direct plating media for the isolation of Salmonella enterica from faeces. J Clin Pathol 55: 286-288.

Oliveira ACS, Matheus C Rosa, Jéssica LB, Yasmine AM, Milena MAF, Gabrielle Virgínia FC, Andréia SS, Roberta SS, Josyane BS, Fábio FL, Talita BR, Carina M. 2018. Validating the Efficiency of a Simplex PCR and Quantitative SYBR Green qPCR for the Identification of Salmonella spp. DNA. J Food Microbiol Saf Hyg 3: 1.
Perelle S, F. Dilasser, Malorny B, Grout J, Hoorfar J, Fach P. 2004. Comparison of PCR-ELISA and LightCycler real-time PCRm assays for detecting Salmonella spp. in milk and meat samples. Mol Cell Probes 18: 409-420.

Piknova L, Kaclikova L, Pangallo D, Polek B, Kuchta T. 2005. Quantification of Salmonella by 5'-nuclease real-time polymerase chain reaction targeted to fim C gene. Curr Microbiol 50: 38-42.

Wang X, Jothikumar M, Griffiths W. 2004. Enrichment and DNA extraction protocols for the simultaneous detection of Salmonella and Listeria monocytogenes in raw sausage meat with multiplex real-time PCR. J Food Prot 67: 189-192. 